\title{
Corrigendum
}

\section{Dexamethasone Stimulated Gene Expression in Peripheral Blood is a Sensitive Marker for Glucocorticoid Receptor Resistance in Depressed Patients}

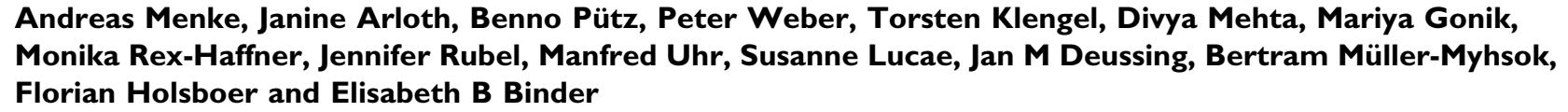
Monika Rex-Haffner, Jennifer Rubel, Manfred Uhr, Susanne Lucae, Jan M Deussing, Bertram Müller-Myhsok, Florian Holsboer and Elisabeth B Binder

Neuropsychopharmacology (2012) 37, 1972; doi: I0.1038/npp.2012.21

Correction to: Neuropsychopharmacology (2012) 37, 1455-1464; doi:10.1038/npp.2011.331; published online 11 January 2012

In this article, there is an error on page 8, right column, line 3. The sentence should read as follows: Nonetheless, these transcripts also correctly classified $77.3 \%$ of the dexamethasone suppressor patients, indicating that they suffer from a GR-resistance that is not evident in the DST, but observable in the dexamethasone-stimulated gene expression pattern. 